\title{
Science Process Skills and Attitudes toward Science among Palestinian Secondary School Students
}

\author{
Afif Hafez Zeidan ${ }^{1, *} \&$ Majdi Rashed Jayosi ${ }^{2}$ \\ ${ }^{1}$ Head of Psychology Department, Al-Quds University, Jerusalem, Palestine \\ ${ }^{2}$ Department of Technology Education, Palestine Technical University, Tulkarm, Palestine \\ *Corresponding author: Head of Psychology Department, Al-Quds University, Jerusalem, Palestine. E-mail: \\ afzeidan@edu.alquds.edu
}

Received: November 14, 2014

Accepted: December 15, 2014 Online Published: December 23, 2014

doi:10.5430/wje.v5n1p13

URL: http://dx.doi.org/10.5430/wje.v5n1p13

\begin{abstract}
The aims of this study were to investigate the relationship between the Palestinian secondary school students knowledge level of science process skills and their attitudes toward science, and the effect of gender and residence of these students on their knowledge level of science process skills and on their attitudes toward science. The study used an 18 - question science process skills test and a 25 -item attitudes toward science questionnaire. The association between knowledge level of science process skills and attitudes toward science were significant with a correlation coefficient of 0.69 . The results of the study indicated that there were significant differences in science process skills due to gender favoring females; and due to residence favoring villages students. However, there were no significant differences in attitudes toward science due to the variables.
\end{abstract}

Keywords: science process; attitudes; science education; Palestinian students; secondary students

\section{Introduction}

One of the most important goals of science education is to teach students how to get involved in inquiry. In other words, students should integrate skills, knowledge, and attitudes to develop a better understanding of scientific concepts. So teachers must focus on teaching science skills such as facts, concept and theories, to encourage students through scientific investigation. Science process skills are a necessary tool to produce and use scientific information, to perform scientific research, and solve problems (Aktamis \&Ergin, 2008). Colvill and Pattie (2002) postulated that the activities which consist of basic and integrated process skills are the key factor of scientific / science literacy and the key dimension of scientific / science literacy. Padilla (1990) classified these skills as basic and integrated due to their usage according to students progressional phases. According to Skamp (1988) basic science process skills such as observing, using numbers and classifying are the foundation for the acquisition of integrated science process skills. Both basic and integrated scientific skills are important in any scientific investigation such as conducting projects and carrying out experiments.

Science process skills are known as procedural skills, experimental and investigating science habits of mind or scientific inquiry abilities (Harlen, 1999). Appropriate selections of science process skills can be taught and studied in the early years of primary school the basic skills considered as prerequisite to learning the Integrated skills. The young students can be given the opportunity to observe, handle things and explore the environment (Ango, 2002). Chiappetta and Koballa, (2002) classified basic and integrated scientific skills as follows:

\subsection{Basic Science Process Skills}

Observing: Noting the properties of objects and situations using the five senses. It is description of what was actually perceived.

Measuring: Expressing the amount of an object or substance in quantitative terms.

Inferring: Giving an explanation for a particular object or substance in quantitative terms.

Classifying: Relating objects and events according to their properties or attributes. 
Predicting: Forecasting a future occurrence based on past observation or the extension of data.

Communicating: Using words, symbols, or graphics to describe an object, action or event.

\subsection{Integrated Science Process Skills}

Controlling variables: Manipulating and controlling properties that relate to situations events for the purpose of determining causation.

Hypothesizing: Stating tentative generalization of observations or inferences that may be used to explain a relatively larger number of events but that is subject to immediate or eventual testing by one or more experiments.

Experimentation: Testing a hypothesis through the manipulation and control of independent variables and noting the effects on a dependent variable: interpreting and presenting results in the form of a report that others can follow to replicate the experiment.

Data Interpreting: Arriving at explanations, inference, or hypotheses from data that have been graphed or placed in a table.

The development of a positive attitude toward science is one of the most important goals of the curriculum (Thomas, Koballa \& Crawley, 1985). As well, there have been a number of studies that examined attitudes toward science in general (Delpech, 2002; Ebenezer \& Zoller, 1993). However, teachers concentrate almost exclusively on the assessment of academic achievement but not on student attitudes or Science process skills and the relationship between them. Furthermore, all of these studies investigated attitudes and Science process skills under stable political conditions for the school context. In this study, we investigated Science process skills and attitudes toward Science for students living in the Palestine, which has been in a state of conflict with Israel for tens of years.

Attitudes are general dispositions that stand behind people's evaluations and emotional feelings. Attitudes arise from human needs and are expressions of people's intellectual processes (Wheeler, Goodale, \& Deese, 1974). The term attitudes toward science should be used to refer to a general, enduring, positive or negative disposition about science (Thomas, Koballa \& Crawley, 1985). An attitude consists of three aspects: affective, cognitive, and behavioral (Arnson, Wilson, \& Akert, 1994). An affective component consists of an individual's dispositions about the attitude object. A cognitive component is the individual's beliefs or knowledge about the attitude object, and the behavioral component is the individual's predisposition to act toward the attitude object in a particular way (Gall, Gall, \& Borg, 2003).

\section{Review of Literature}

Al-rabaani (2014) investigated the acquisition of science process skills by Omani's pre-service social studies' teachers. Data were collected using a questionnaire which consisted of 14 items covering basic and integrated science process skills. The questionnaire was distributed to all 59 social studies students' teachers in the college of education at Sultan Qaboos University in the Sultanate of Oman. The results showed that they had moderate acquisition of science process skills and there was no difference due their gender.

Bang and Baker (2013) investigated the effect of high schools' gender organization on Korean tenth-grade students' science achievements, and their attitudes towards science. Three schools, three principals, three science teachers, and 302 tenth-grade students from their respective school types responded to an initial survey, and eleven academically outstanding students were subsequently interviewed. Results indicated that the male and female students from the co-ed school had significantly higher science achievement and positive attitudes towards science.

Feyzioglu, Demirdag, Akyildiz and Altun (2012) studied the validity and reliability of science process skills for secondary students. The test was applied on 222 students from a vocational high school in Turkey. The test consisted of 30 multiple-choice questions, the reliability of the test was (0.83). The test consisted of sub-dimensions such as, observing, classifying, measuring, communicating, inferring, predicting, formulating hypotheses, identifying variable, organizing data, and interpreting it, designing investigations, acquiring data. The results of the confirmatory factor analysis supported validity and reliability of the test.

Ozgelen (2012) studied the students science process skills within a cognitive domain framework. A sample of 306 sixth and seventh grade students from public, private, and bussed schools. The Turkish integrated process skills test was used to measure scientific process skills, and the findings showed generally low scores. private schools students had higher scores compared to public and bussed school students.

Zeidan (2010) investigated the relationship between the attitudes toward biology and perceptions of biology learning 
environment among Grade 11 students $(N=190)$ in Tulkarm district, Palestine, and. The study used a 30-item attitude toward biology questionnaire and a 32-item learning environment questionnaire. The association between attitudes toward biology and biology learning environment was significant with a correlation coefficient of 0.366. The results of the study indicated that there were significant gender differences in attitudes toward biology, favoring females.

Downing and Filer (1999) explored the relationship between pre-service elementary teachers competences in science process skills and attitudes toward science. The sample set consisted of 46 students enrolled in an elementary math and science methods course during their first senior semester. The research found a significant relationship between how well teachers performed science process skills and their attitudes toward science.

\section{Statement of Problem}

Science educators and Specialists believe that teaching science must be divided into two parts: (material and method). The first one includes the facts, concepts, laws and theories, while the second part includes scientific thinking, critical thinking and scientific processes. In general, teachers evaluate the first part and ignore the second because they feel that teaching thinking skills and science processes is a waste of time and effort. According to Blooms taxonomy, educational objectives are divided into three "domains": cognitive, affective and psychomotor. In the Palestinian schools, science teachers focus on the cognitive outputs rather than the other outputs such as those related to the effective domain which includes students attitudes toward science. In Palestine, the secondary school student's knowledge of scientific processes and their attitudes towards science has never been studied. The aim of this study was to evaluate the science process skills and the attitudes toward science among secondary school students.

\section{Objective of the Study}

This study investigated the science process skills and attitudes toward science among the Palestinian secondary school students in the cities and villages of Tulkarm district, Palestine. These data were used to determine whether there are significant differences in science process skills and attitudes toward science for students due to genders and residency. Furthermore, it analyzed the relationship between the science process skills and attitudes toward science.

\section{Research Questions}

The following research questions were asked:

1. To what extent is the Palestinian secondary school students knowledge level of science process skills?

2. Are there differences in Palestinian secondary school students knowledge level of science process skills due to gender?

3. Are there differences in Palestinian secondary school students knowledge level of science process skills due to residence?

4. To what extent is the Palestinian secondary school students attitudes level toward science?

5. Are there differences in Palestinian secondary school students attitudes level toward science due to gender?

6. Are there differences in Palestinian secondary school students attitudes level toward science due to residence?

7. Are there any relationship existing between Palestinian secondary school students knowledge level of science process skills and their attitudes toward science?

\section{Methodology}

The research design was developed within a quantitative research tradition. The research methods were used in this study to (a) evaluate science process skills and their attitudes toward science among first secondary Grade students, (b) examine the effects of gender and residence on dependent variables, and (c) examine the relationship between the science process skills and attitudes toward science among First Secondary Grade students.

\subsection{Population and Sample of the Study}

The population of the study consisted of all first secondary Grade students in the district of Tulkarm, Palestine; these students were 17 - years old. A stratified random sample of 159 students ( 72 males and 87 females) was selected (20\% 
of the population) for this study from the city and a village. All students participating in this study were selected from the scientific stream. This sample was judged to represent the characteristics of the target population. These characteristics (gender and residency) of the sample are shown in Table 1.

Table 1. Distribution of the Study Sample According to Gender and Residence ( $\mathrm{N}=159)$

\begin{tabular}{lcc}
\hline & Male & Female \\
\hline City & 35 & 54 \\
Village & 37 & 33 \\
Total & 72 & 87 \\
\hline
\end{tabular}

\subsection{Instruments}

The researchers used two instruments. The first one was the science process skills test (SPST) consisting of (18) items that tests basic and integrated science process skills that was based on the relevant literature (Monica, 2005; Ngoh, 2009). There are 10 items on the basic science process skills, 8 items on the integrated science process skills (see Appendix A for the skill items). Table 2 shows the respective science process skills.

Table 2. Distribution of the Science Process Skills

\begin{tabular}{llll}
\hline Science Process Skills Items & Basic & Science Process Skills Items & Integrated \\
\hline 1,2 & Observation & 11,12 & Controlling variables \\
3,4 & Measuring & 13,14 & Hypothesizing \\
5,6 & Classifying & 15,16 & Experimentation \\
7,8 & Predicting & 17,18 & Data Interpreting \\
9,10 & Communicating & & \\
\hline
\end{tabular}

The second instrument was Attitudes Toward Science Questionnaire (ATSQ) that was based on the relevant literature (Prokop, Tuncer, \& Chuda, 2007; Zeidan, 2010). The 25-items indicated the students agreement or disagreement using Likert-type, a 5 -point response scale $(5=$ strongly agree, $\ldots, 1=$ strongly disagree $)$.

\subsection{Validation of the Instruments}

The two instruments were pilot tested with a group of 25 first secondary Grade students similar to the target population to ensure their comprehensibility, validity, and reliability. The students selected for the pilot study were not included in the main study. The ATSQ results were used to explore the structural validity of the instrument. A factor analysis principal component with varimax rotation was used to confirm the a priori conceptual structure of the ATSQ (Table 3).

Table 3. Factor Loadings for ATSQ Items

\begin{tabular}{|c|c|c|c|c|c|c|c|}
\hline Item & $\begin{array}{l}\text { Factor } \\
\text { analysis }\end{array}$ & Item & $\begin{array}{l}\text { Factor } \\
\text { analysis }\end{array}$ & Item & $\begin{array}{l}\text { Factor } \\
\text { analysis }\end{array}$ & Item & $\begin{array}{l}\text { Factor } \\
\text { analysis }\end{array}$ \\
\hline 1 & 0.63 & 8 & 0.80 & 14 & 0.88 & 20 & 0.90 \\
\hline 2 & 0.84 & 9 & 0.89 & 15 & 0.76 & 21 & 0.78 \\
\hline 3 & 0.64 & 10 & 0.81 & 16 & 0.77 & 22 & 0.73 \\
\hline 4 & 0.89 & 11 & 0.91 & 17 & 0.92 & 23 & 0.86 \\
\hline 5 & 0.74 & 12 & 0.85 & 18 & 0.87 & 24 & 0.85 \\
\hline 6 & 0.87 & 13 & 0.79 & 19 & 0.63 & 25 & 0.71 \\
\hline 7 & 0.82 & & & & & & \\
\hline \multicolumn{2}{|c|}{$\%$ Variance } & 47.06 & & Eigenvalue & & 11.77 & \\
\hline
\end{tabular}

As shown in Table 3, the total amount of variance for the 25 items was $47.06 \%$. The eigenvalue was 11.77 , and all items loaded on the anticipated factor with a loading weight greater than 0.60 . These results strongly supported the claim for structural validity of the ATSQ.

The reliability (internal consistency) of the ATSQ was explored using Cronbach's alpha $(\alpha)$. A pilot test on first secondary Grade students $(N=25)$ was used to establish the reliability of the ATSQ. The Cronbach's $\alpha$ for the ATSQ was (0.95). This reliability made the instruments suitable for this study.

\subsection{Data Collection and Analysis}

The SPST and ATSQ were administered to the sample by the researchers in May of the scholastic year. The SPST 
took the students about 40 minutes to complete, and the ATSQ took about 25 minutes to complete. The responses were entered into a database and verified by the researchers. No questionnaires or item responses were missing as the researchers were present throughout the data collection process to respond to any queries from the students.

The questionnaire results were analyzed using SPSS. Descriptive statistics (means, standard deviations) were computed for responses to each item of the questionnaire. t-test was used to determine variations in the means by gender. Subsequently, one way ANOVA was used to examine whether or not there were statistically significant differences in the level of science process skills and attitudes level toward science among Palestinian secondary school students due to their residence. Pearson correlation coefficient was used to investigate the relationship between science process skills and attitudes toward science.

\section{Results}

\subsection{Result Related to the First Question}

"To what extent is the Palestinian secondary school students knowledge level of science process skills?"

To answer this question, means, standard deviations and percentage have been used for all students on 18 items were calculated, besides the values for SPST, the mean and standard deviations for each component skill is also included in table 4.

Table 4. Means, Standard Deviations, and Percentage for Each Component Skill

\begin{tabular}{llllll}
\hline No & Skills & Max & Mean & S.D & Percent \\
\hline 1 & Observation & 2 & 1.63 & 0.55 & $81.5 \%$ \\
2 & Measuring & 2 & 1.40 & 0.68 & $70.0 \%$ \\
3 & Classifying & 2 & 1.13 & 0.71 & $56.5 \%$ \\
4 & Predicting & 2 & 1.50 & 0.68 & $75.5 \%$ \\
5 & Communicating & 2 & 1.28 & 0.79 & $64.0 \%$ \\
6 & Controlling variables & 2 & 0.81 & 0.70 & $40.5 \%$ \\
7 & Hypothesizing & 2 & 1.25 & 0.79 & $62.5 \%$ \\
8 & Experimentation & 2 & 0.96 & 0.69 & $0.48 \%$ \\
9 & Data Interpreting & 2 & 1.38 & 0.73 & $69.0 \%$ \\
& SPST & 18 & 11.64 & 3.76 & $64.7 \%$ \\
\hline
\end{tabular}

As shown in Table 4, the Observation skill gets rank one with its mean value (1.63) and standard deviation (0.55). Also, Predicting skill gets rank two with its mean value (1.50) and standard deviation (0.68). Likewise, Measuring skill gets rank three with its mean value (1.40) and standard deviation (0.68). The average of SPST was (11.64) which is $(64.7 \%)$, and the score for the individual process range from $(0.81)$ to (1.63).

\subsubsection{Differences in the Knowledge Level of Science Process Skills Due to Gender}

To answer the second question of the study: "Are there differences in Palestinian secondary school students knowledge level of science process skills due to gender?" The researchers used the independent t-test to analyze the data from the SPST. Table 5 shows the results.

Table 5. t-test of the Differences among the Means of Knowledge Level Of Science Process Skills Due to Gender

\begin{tabular}{llllll}
\hline Variable & N & Mean & S.d & t-value & Sig \\
\hline Male & 72 & 10.31 & 4.23 & 4.24 & $0.00^{*}$ \\
Female & 87 & 12.73 & 2.90 & & \\
\hline$* p<0.01$ & & & & &
\end{tabular}

As shown in Table 5, shows that the means of knowledge level of science process skills for the males were (10.31) and the means of knowledge level of science process skills for the females were (12.73), The results of the $t$-test revealed a significant gender main effect $(t=4.24, p=0.00)$ favoring female students.

\subsubsection{Differences in the Knowledge Level of Science Process Skills Due to Residence}

To answer the third question of the study: "Are there differences in Palestinian secondary school students knowledge level of science process skills due to residence?" The researchers used the t-test to analyze the data from the SPST. Table 6 shows the results. 
Table 6. t-test of the Differences among the Means of Knowledge Level of Science Process Skills Due to Residence

\begin{tabular}{llllll}
\hline Variable & N & Mean & S.d & t-value & Sig \\
\hline City & 89 & 10.53 & 3.95 & 4.39 & $0.00 *$ \\
Village & 70 & 13.04 & 3.00 & & \\
\hline$* p<0.01$ & & & &
\end{tabular}

Table 6 shows that the means of knowledge level of science process skills for the city were (10.53) and the means of knowledge level of science process skills for the village were (13.04). The results of the $t$-test revealed significant residence main effect $(t=4.39, p=0.00)$ favoring village students.

\subsection{Result Related to the Forth Question}

"To what extent is the Palestinian secondary school students attitudes level toward science?" To answer this question, the following key has been used to judge the paragraphs of the questionnaires: An average of less than 2.33 indicates a low score; an average of 2.33 - 3.67, indicates a moderate score; an average of more than 3.67 indicates a high score. Means and standard deviations of each item were calculated as shown in Table 7.

Table 7. Means and Standard Deviations of the Palestinian Secondary School Students Attitudes Level toward Science

\begin{tabular}{|c|c|c|c|c|}
\hline Rank & Items & Mean & SD & Estimation \\
\hline 1 & $\begin{array}{l}\text { I like practical work in science because I can use } \\
\text { equipment and scientific tools. }\end{array}$ & 3.91 & 1.33 & High \\
\hline 2 & $\begin{array}{l}\text { It is exciting to learn about new things happening in } \\
\text { science. }\end{array}$ & 3.89 & 1.25 & High \\
\hline 3 & $\begin{array}{l}\text { I like science because it helps me to develop the skills of } \\
\text { thinking. }\end{array}$ & 3.88 & 1.19 & High \\
\hline 4 & $\begin{array}{l}\text { I would like to do more science activities in science } \\
\text { lessons. }\end{array}$ & 3.73 & 1.30 & High \\
\hline 5 & Science lessons are interesting. & 3.72 & 1.08 & High \\
\hline 6 & Science excites questions, opinions and ideas. & 3.71 & 1.17 & High \\
\hline 7 & Science is not important for society. & 3.70 & 1.38 & High \\
\hline 8 & I like reading science magazines and books. & 3.58 & 1.19 & Moderate \\
\hline 9 & Practical work in science is exciting. & 3.55 & 1.32 & Moderate \\
\hline 10 & $\begin{array}{l}\text { I would like to discuss scientific topics with my } \\
\text { classmates. }\end{array}$ & 3.52 & 1.30 & Moderate \\
\hline 11 & I like watching science programs on TV. & 3.47 & 1.19 & Moderate \\
\hline 12 & $\begin{array}{l}\text { I would like to do more science activities outside of } \\
\text { school. }\end{array}$ & 3.44 & 1.21 & Moderate \\
\hline 13 & Practical work in science is useless. & 3.41 & 1.48 & Moderate \\
\hline 14 & Practical work in science is boring. & 3.24 & 1.42 & Moderate \\
\hline 15 & $\begin{array}{l}\text { I like science lessons more than most other subjects } \\
\text { lessons. }\end{array}$ & 3.23 & 1.08 & Moderate \\
\hline 16 & I look forward to my science lessons. & 3.03 & 1.04 & Moderate \\
\hline 17 & Science lesson is boring. & 3.07 & 1.32 & Moderate \\
\hline 18 & I would like to do more science in school. & 3.19 & 1.29 & Moderate \\
\hline 19 & I learn science quickly. & 3.08 & 1.14 & Moderate \\
\hline 20 & I would like to study science at university. & 3.01 & 1.29 & Moderate \\
\hline 21 & I feel helpless when doing science. & 2.99 & 1.28 & Moderate \\
\hline 22 & I would like to do posters science in school. & 2.97 & 1.12 & Moderate \\
\hline 23 & In my science class, I understand everything. & 2.86 & 1.14 & Moderate \\
\hline 24 & I find science difficult & 2.69 & 1.17 & Moderate \\
\hline 25 & I would like to become a science teacher. & 2.28 & 1.24 & Low \\
\hline & The whole instrument & 3.33 & 0.68 & Moderate \\
\hline
\end{tabular}

As shown in Table 7, the item " I like practical work in science because I can use equipment and scientific tools " gets rank one with its mean value (3.91) and standard deviation (1.33). Also, the item " It is exciting to learn about 
new things happening in science " gets rank two with its mean value (3.89) and standard deviation (0.25). The mean for whole sample of the study was (3.33), and it meets the estimation of Likert scale of Moderate score.

\subsubsection{Differences Due to Gender}

To answer the fifth question of the study: "Are there differences in Palestinian secondary school students attitudes level toward science due to gender?" The researchers used the t-test to analyze the data from the questionnaire. Table 8 shows the results.

Table 8. t-test of the Differences among the Means of Attitudes Level Toward Science Due to Gender

\begin{tabular}{llllll}
\hline Variable & N & Mean & S.d & t-value & Sig \\
\hline Male & 72 & 3.23 & 0.62 & 1.49 & 0.14 \\
Female & 87 & 3.40 & 0.72 & & \\
\hline
\end{tabular}

Table 8 shows that the means of the attitudes level toward science for the males were (3.23) and the means of the attitudes level toward science for the females were (3.40), and non significant gender main effect $(t=1.49, p=0.14)$.

\subsubsection{Differences Due to Residence}

To answer the sixth question of the study: "Are there differences in Palestinian secondary school students attitudes level toward science due to residence?" The researchers used the t-test to analyze the data from the questionnaire. Table 9 shows the results.

Table 9. t-test of the Differences among the Means of Attitudes Level Toward Science Due to Residence

\begin{tabular}{llllll}
\hline Variable & N & Mean & S.d & t-value & Sig \\
\hline City & 89 & 3.37 & 0.57 & 0.86 & 0.39 \\
Village & 70 & 3.27 & 0.80 & & \\
\hline
\end{tabular}

As shown in Table 9, the means of attitudes level toward science for the city were (3.37) and the means of attitudes level toward science for the village were (3.27), and non significant residence main effect $(t=0.86, p=0.39)$.

\subsection{Result Related to the Forth Question}

"To answer the seventh question of the study: "Are there any relationship existing between Palestinian secondary school students knowledge level of science process skills and their attitudes toward science?" The association between Palestinian secondary school students knowledge level of science process skills and their attitudes toward science was explored by calculating the correlation. A significant $(p=0.03)$ positive correlation of $(0.69)$ was found among these variables.

\section{Discussion and Conclusions}

\subsection{Science Process Skills among the Palestinian Secondary School Student}

The finding of the study shown in table (4) revealed that the average of SPST was (11.64), and the percentage was $(64.7 \%)$, which is moderate.

The results show that more Palestinian secondary school students selected the correct options for items related to the skill of Observation, Predicting and Measuring. They found the skill of observation and predicting easier than the other skills. While fewer of target students selected the correct option for items related to the skill of controlling variables and experimentation. The researchers believe that the Palestinian secondary school students have less experience in controlling variables and experimentation. This finding may be due to the traditional teaching method used by the teachers. The traditional methods cannot develop the integrated science process skills. The finding of this study supports the results of some previous studies, which showed that teacher and students teachers' did not reach the high level of acquisition of science process skills (Al-rabaani, 2014; Ozgelen, 2012).

The result in table 5 shows a $t$-value of 4.24 , with $p<0.01$. this $p$-value is less than 0.01 . This means that there are significant differences in mean performance of females and males knowledge level of science process skills. Female's have more score compared to male's score. The researchers believe that the reason for this is females in Palestine are more disciplined than males because females more serious in science learning because of the opportunities offered to females to complete their university studies. This is consistent with Al-rabaani (2014) who found that there was no difference in acquisition of science process skills by Omani's pre-service teachers due their gender.

The results of the $t$-test revealed significant residence main effect $(t=4.39, p=0.00)$ favoring village students. The 
reason for this is that village students are interested in learning to get a job, while the city's students work in business. They are not interested in getting a government job, and this reduces the interest in education in general and in science process skills in particular.

\subsection{Attitudes toward Science among the Palestinian Secondary School Student}

The finding of the study shown in table (7) revealed that the average of ATQS was (3.33), and the percentage was $(66.6 \%)$ which is moderate.

The result in table 8 shows a t-value of 1.49 , with $p>0.05$. This $p$-value is more than 0.01 . This means that there is no significant difference in the means of attitudes level toward science due to gender. This is because Palestinian school students, females and males were coming from the same classes. they were subjected to the same conditions of teaching and learning. The result in table 9 shows a t-value of 0.86 , with $\mathrm{p}>0.05$. This $\mathrm{p}$-value is more than 0.05 . This means that there is no significant difference in the means of attitudes level toward science due to residence. In Palestinian villages' and city's schools, students are interested in the cognitive domain rather than the affective one which includes attitudes. Palestinian villages and city's have the same culture and the same curriculum science education. The researchers believe that these nonsignificant differences are due to modern communications (e.g., satellite, mobile telephones, Internet, etc.) which are available in both villages and cities, which makes the access and flow of information equal. The finding of this study supports the results of Bang and Baker (2013) whose found that the male and female students had significantly higher positive attitudes towards science.

8.3 Relationship between the Science Process Skills and Attitudes toward Science among Palestinian Secondary School Students

The significant positive correlation between science process skills and attitudes toward science among Palestinian secondary school students has been found. The researchers believe that the positive attitudes toward science makes the students more interested in focusing on science process. In other words when the students understand the science process skills, science becomes more interesting to them, which increases the positive attitudes towards science. Downing and Filer (1999) reported that there was a significant relationship between science process skills among teachers and their attitudes toward science.

\section{References}

Al-rabaani, A. (2014). The acquisition of science process skills by Omani's pre-service social studies' teachers. European Journal of Educational Studies, 6(1), 13-19.

Aktamis, H., \& Ergin, O. (2008). The effect of scientific process skills education on students scientific creativity, science attitudes and academic achievements. Paper presented at Asia-Pacific Forum on Science Learning and teaching. June 2008.

Ango, M. (2002). Mastery of science process skills and their effective use in the teaching of science: An Educology of science Education in the Nigerian context. International Journal of Educology, 16(1), 11-30.

Arnson, E., Wilson, D., \& Akert, M. (1994). Social psychology. The heart and the mind. New York: Harper Collins.

Bang, E., \& Baker, D. (2013). Gender differences in Korean high school students' science achievements and attitudes towards science in three different school settings. Mevlana International Journal of Education, 3(2), 27-42. http://dx.doi.org/10.13054/mije.13.11.3.2

Chiappetta, E., \& Koballa, T. (2002). Science Instruction in the Middle and Secondary Schools (5 $5^{\text {th }}$ ed). Upper Saddle River, NJ: Merrill Prentice Hall.

Colvill, M., \& Pattie, I. (2002). The building blocks for scientific literacy. Australian Primary \& Junior Science Journal, 18(3), 20-30.

Delpech, R. (2002). Why are school students bored with science? Journal of Biological Education, 36(4), 156-157. http://dx.doi.org/10.1080/00219266.2002.9655825

Downing, J., \& Filer, J. (1999). Science process skills and attitudes of pre-service elementary teachers. Journal of Elementary Science Education, 11(2), 57-64. http://dx.doi.org/10.1007/BF03173838

Ebenezer, J., \& Zoller, U. (1993). Grade 10 students' perceptions of and attitudes toward science teaching and school science. Journal of Research in Science Teaching, 30(2), 175-186. http://dx.doi.org/10.1002/tea.3660300205

Feyzioglu, B., Demirdag, B., Akyildiz, M., \& Altun, E. (2012). Developing a of a science process skills test for 
secondary students: validity and reliability study. Educational sciences: Theory and Practice, 12(3), 1899-1906.

Gall, M. D., Gall, J. P., \& Borg, W. R. (2003). Educational research, an introduction (7 $7^{\text {th }}$ ed.). Boston: Allyn \& Bacon.

Harlen, W. (1999). Purposes and procedures for assessing science process skills. Assessment in Education, 6(1), 129-144. http://dx.doi.org/10.1080/09695949993044

Monica, K. (2005). Development and validation of a test of integrated science process skills for the further education and training learners. Unpublished Master's thesis, University of Pretoria. South Africa.

Ngoh, T. (2009). Mastery of the science process skills. Unpublished manuscript.

Ozgelen, S. (2012). Students science process skills within a cognitive domain framework. EURASIA Journal of Mathematics, Science\& Technology Education, 8(4), 283-292. http://dx.doi.org/10.12973/eurasia.2012.846a

Padilla, M. (1990). The science process skills. Paper 9004 in the series, science matters-to the science teacher, published by the National Association for research in science Teaching. Retriever May 24, 2011, from http;/www.narst.org/publications/research/skill.cfm.

Prokop, P., Prokop, M., \& Tunnicliffe, S. (2007). Is biology boring? Student attitudes toward biology. Journal of Biological Education, 42(1), 36-39. http://dx.doi.org/10.1080/00219266.2007.9656105

Skamp, K. (1988). Teaching Primary science constructively. ( $3^{\text {rd }}$ ed). Australia: Cengage Learning Australia Pty Limited.

Thomas, R., Koballa, Jr., \& Crawley, F. (1985). The influence of attitude on science teaching and learning. School Science and Mathematics, 85(3), 222-232. http://dx.doi.org/10.1111/j.1949-8594.1985.tb09615.x

Wheeler, L., Goodale, R., \& Deese, J. (1974). General psychology. Oxford, UK: Allyn \& Bacon.

Zeidan, A. (2010). The relationship between grade 11 Palestinian attitudes toward biology and their perceptions of the biology learning environment. International Journal of Science and Mathematics Education, 8(5), 783 - 800. http://dx.doi.org/10.1007/s10763-009-9185-8

Appendix A

\section{Science Process Skills Test (SPST)}

Circle the letter of the most appropriate answer.

1. Which of the following is not a characteristic of a cola?
A. it is favorite
B. it is colorless
C. it is liquid
D. it is black

2. Which of the followings could be observed with the sense of sight?

A. the temperature of the air

B. the ice floats on water

C. the sweetness of a new chemical

D. the smell of perfume

3. What unit of work would best measure the weight of Engagement ring?
A. kilograms
B. grams 
C. pounds

D. centimeters

4. When converting from $(\mathrm{cm})$ to (inch) in metric system:
A. conversion formulas must be used
B. there are two $(\mathrm{cm})$ in each (inch)
C. $(\mathrm{cm})$ is equal to (inch)
D. you cannot convert from $(\mathrm{cm})$ to (inch)

5. Here is some information about students in a Palestinian university.

\begin{tabular}{lllll}
\hline Name & Birthday & Gender & Nationality & Year entered \\
\hline Ahmad & March 1995 & Male & Palestinian & 2012 \\
Mohamad & April 1994 & Male & Palestinian & 2013 \\
Issa & June 1995 & Male & Palestinian & 2012 \\
Musa & May 1993 & Female & Palestinian & 2012 \\
Ibrahim & April 1992 & Male & Palestinian & 2011 \\
\hline
\end{tabular}

Which of the following categories would not allow you to separate these students into at least two different groups?
A. gender
B. year of birth
C. nationality
D. year entered

6. Which of the following classification do you think would be the best for these shapes
A. square vs. no square
B. circular vs. triangle
C. curved ribs vs. straight ribs
D. individual numbers for ribs vs. paired number

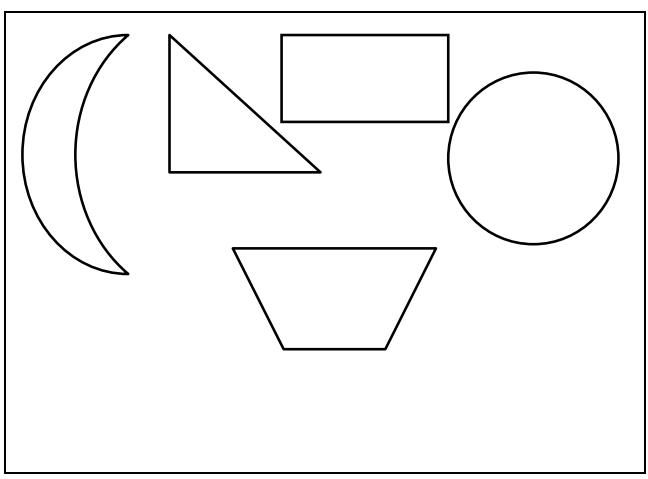

7. Recently, Nancy heard sirens roaring from a nearby street. The next day when she went to school she saw a house covered with wide black spots and smoke. The most reasonable inference that she could make when describing what she saw was:
A. the house was destroyed by a tornado
B. the house was destroyed by a wild animal
C. the house was destroyed by a fire
D. the house was destroyed by a hurricane

8. During the night, Sunny was awakened by a thunderstorm. Walking to school the next day, he saw a large tree blocking the street. The best inference that he could make is that the tree was:
A. hit by a bulldozer
B. bombed by an airplane
C. knocked down by the storm 
D. destroyed by a fire.

9. The best style to show the amounts of rain for the past five years was
A. numbers
B. graphs
C. reports
D. images

10. The best way to guide the university visitors was
A. a reception office
B. the students
C. extension Maps
D. images

11. A farmer wants to increase the amount of tomato produce, he think that the amount of water and fertilize given to tomato plant and the sunlight, affects the group of students conducted an experiment to determine the effect of heat on the amount of tomato produce.

Which of the following is NOT likely to be a factor that affects the amount of tomato produce?
A. the type of soil used
B. the amount of water given to tomato plant
C. the amount of sunlight
D. the amount of fertilize given to tomato plant

12. Ahmad and Ibrahim want to know if there is any difference between the mileage expected from bicycle tires from two different manufacturers. Ahmad will put one trademark on his bicycle and Ibrahim will put the other trademark on his bicycle.

Which of the following variables would be the most important to control in this experiment?
A. the weight of the bicycle used
B. the time of day the test is made
C. the physical condition of the bike rider
D. the number of miles traveled by each type of tire

13. Khaled noticed that the bread decays quickly if he exposed to room temperature before it is eaten. He also noticed that it takes a longer time for it to decay if it is left in a refrigerator. He wondered whether it is the temperature or the refrigerator that causes the leaved bread to decay.

Which of the following statements could be tested to answer Khaled's concerns?
A. bread becomes better if it exposed to room temperature
B. refrigerator is necessary for bread to decay
C. bread takes a longer time to decays if it is left in a refrigerator
D. room temperature stimulates bread decay

14. A farmer combines the production of strawberries from three greenhouses, the product is usually more in some greenhouses than the other. He makes some guesses about why the product is different. He thinks that the amount of water and fertilize given to a tomato plant and the sunlight affects the group of students conducted an experiment to determine the effect of heat on the amount of tomato produce.

Which of the followings is a suitable testable explanation for the difference in the product of greenhouses?
A. the greenhouses that receive more sunlight have more product
B. greenhouses that have lower product are more suitable for another plant
C. strawberries is not profitable
D. the low amount of strawberries is preferred by customers 
15. A student wants to know the effect of acid rain, upon a fish population. He takes two jars and fills each of the jars with the same amount of water. He adds fifty drops of vinegar (acid) to one jar and adds nothing extra to the other. He then puts 10 similar fish in each jar. Both groups of fish are cared for (oxygen, food, etc,) in identical fashion. After observing the behavior of the fish for a week, he makes his conclusions.

What would you suggest to improve this experiment.

A. prepare more jars with different amounts of vinegar

B. add more fish to the two jars already used

C. add more jars with different kinds of fish and different amounts of vinegar in each jar

D. add more vinegar to the jars already in use

16. Mariam thinks that the more air pressure in football, the further it moves when it is kicked. To investigate her idea, she uses several footballs and an air pump with a pressure gauge. How should Mariam test her idea?
A. kick the footballs with different amounts of force from the same point
B. kick the footballs having different air pressure from the same point
C. kick the footballs having the same air pressure at different angles on the ground
D. kick the footballs having different air pressure from different points on the ground

17. Highest daily temperature recorded each day for a week is shown on the data table.

\begin{tabular}{lllllll}
\hline Sunday & Monday & Tuesday & Wednesday & Thursday & Friday & Saturday \\
\hline $8^{\circ} \mathrm{C}$ & $7^{\circ} \mathrm{C}$ & $0^{\circ} \mathrm{C}$ & $15^{\circ} \mathrm{C}$ & $23^{\circ} \mathrm{C}$ & $21^{\circ} \mathrm{C}$ & $19^{\circ} \mathrm{C}$ \\
\hline
\end{tabular}

Which of the following statements is correct?
A. it snowed all day on Friday
B. monday had the lowest temperature
C. the highest temperature was recorded on Thursday
D. the temperature was higher on Wednesday than on Saturday

18. A student wants to know the relationship between light intensity and Alge photosynthesis. He carried out an investigation and got the following results.

\begin{tabular}{lllllllll}
\hline Light intensity (candela) & 250 & 500 & 900 & 1200 & 1800 & 2400 & 2800 & 3100 \\
\hline Volume of CO2 (ml) min & 0.3 & 0.5 & 0.8 & 1.1 & 2.2 & 2.00 & 1.7 & 1.2 \\
\hline
\end{tabular}

Which of the following statements correctly describes what these results show

A. as light intensity increases, photosynthesis also increases

B. as photosynthesis increases, light intensity also increases

C. as photosynthesis increases, light intensity increases then decreases

D. as light intensity increases, photosynthesis increases then decreases 